\title{
HUBUNGAN ANTARA PENGETAHUAN IBU NIFAS DENGAN SIKAP DALAM MELAKUKAN PERAWATAN PAYUDARA DI RUMAH SAKIT KARTIKA HUSADA KABUPATEN KUBU RAYA TAHUN 2017
}

\section{Yuliana $^{1}$, Melyani ${ }^{2}$}

\author{
Akademi Kebidanan Panca Bhakti Pontianak
}

Email korespondensi: akbidpbpontianak@gmail.com

\begin{abstract}
Abstrak
Perawatan Payudara merupakan suatu tindakan merawat payudara yang dilaksanakan baik oleh pasien maupun dibantu orang lain yang dilaksanakan mulai dari hari pertama atau kedua setelah melahirkan. Payudara bengkak biasanya terjadi pada hari-hari pertama kelahiran bayi, data yang didapatkan dari Rumah Sakit Kartika Husada pada bulan Januari hingga Maret 2017 terdapat lima kali kejadian payudara bengkak. Tujuan penelitian ini adalah untuk mengetahui hubungan antara pengetahuan ibu nifas dengan sikap dalam melakukan perawatan payudara di Rumah Sakit Kartika Husada Tahun 2017. Penelitian ini menggunakan metode analitik korelasi dengan pendekatan cross sectional, teknik pengumpulan data menggunakan kuisioner dengan jumlah sampel pada bulan April sebanyak 40 responden yaitu ibu nifas yang mendapat pelayanan di Rumah Sakit Kartika Husada. Analisis data menggunakan analisis univariat untuk menguji pengetahuan dan sikap responden dan analisis bivariat untuk mengetahui hubungan antara variabel. Hasil penelitian univariat dengan distribusi frekuensi menunjukkan bahwa sebagian responden $(52,5 \%)$ berpengetahuan kurang, kategori sikap menunjukkan bahwa sebagian responden $(52,5 \%)$ memiliki sikap tidak mendukung. Hasil analisis bivariat dengan distribusi Chi-Square diperoleh nilai 0,01 (p-value < 0,05). Hasil analisis bivariat menunjukkan bahwa sangat sedikit dari responden (19\%) yaitu 4 orang berpengetahuan kurang dengan sikap mendukung. Kesimpulan penelitian ini yaitu ada hubungan antara pengetahuan ibu nifas dengan sikap dalam melakukan perawatan payudara di Rumah Sakit Kartika Husada tahun 2017. Saran kepada petugas kesehatan untuk melakukan penyuluhan tentang perawatan payudara dengan cara membagikan brosur, leaflet atau menempelkan gambar tentang perawatan payudara.
\end{abstract}

Kata Kunci: Pengetahuan, Sikap, Perawatan Payudara, Ibu Nifas

\section{Pendahuluan}

Masa nifas atau puerperium berasal dari bahasa latin yaitu puer yang artinya bayi dan paraous yang artinya melahirkan atau berarti masa sesudah melahirkan (Saleha, 2009). Pada masa ini terjadi perubahan-perubahan fisiologis yaitu salah satunya adalah laktasi atau pengeluaran air susu (Maryunani, 2009).

Laktasi adalah keseluruhan proses menyusui mulai dari ASI diproduksi sampai proses bayi menghisap dan menelan ASI. Masa laktasi mempunyai tujuan yaitu untuk meningkatkan pemberian ASI ekslusif dan meneruskan pemberian ASI sampai anak umur 2 tahun secara baik dan benar serta anak mendapatkan kekebalan tubuh secara alami

\footnotetext{
${ }^{1}$ Dosen Akademi Kebidanan Panca Bhakti Pontianak

${ }^{2}$ Dosen Akademi Kebidanan Panca Bhakti Pontianak
}

(Wulandari dan Ambarawati, 2008).

Diperlukan suatu upaya untuk meningkatkan produksi ASI semasa nifas salah satunya adalah dengan perawatan payudara sehingga hak-hak bayi untuk mendapatkan asi dari ibunya terpenuhi.

\section{The American Academy of Pediatrics} merekomendasikan ASI ekslusif selama 6 bulan pertama dan selanjutnya minimal 1 tahun. World Health Organization (WHO) merekomendasikan ASI eksklusif selama 6 bulan, menyusui dalam 1 jam pertama setelah melahirkan, menyusui setiap bayi mau, tidak menggunakan botol dan dot (Rahmawati dan Proverawati, 2010). 
United Nations International Children's Emergency Fund (UNICEF) memperkirakan bahwa pemberian ASI ekslusif sampai usia 6 bulan dapat mencegah kematian 1,3 juta anak berusia dibawah lima tahun (Sujiyanti, 2010). Suatu penelitian di Ghana yang diterbitkan dalam jurnal pediatric menunjukkan 16\% kematian bayi dapat dicegah dengan pemberian ASI sejak hari pertama kelahirannya (Sujiyanti, 2010).

Mengacu pada target rencana strategis pada tahun 2015 di Indonesia sebesar 39\%, maka secara nasional cakupan pemberian ASI ekslusif pada bayi kurang dari 6 bulan sebesar $55,7 \%$ telah mencapai target. Cakupan pemberian ASI di Kalimantan Barat sendiri sudah mencapai $68,4 \%$ yang artinya telah mencapai target yang diinginkan (Profil Kesehatan Indonesia, 2015).

Peran penting seorang ibu sebagai penentu pertumbuhan dan kesehatan anak dikemudian hari tidak berhenti begitu melahirkan bayinya, menyusui masih merupakan mata rantai untuk melahirkan generasi yang cerdas yang terbukti secara ilmiah. Hal ini terbukti dengan banyaknya manfaat yang diperoleh dari kandungan ASI. Melihat betapa pentingnya payudara sebagai penghasil ASI maka ibu juga harus mengetahui perawatan payudara yang benar agar bayi dapat segera menyusui dan mendapatkan kecukupan ASI dari sang ibu. Perawatan payudara pada dasarnya tidak hanya dilakukan sebelum melahirkan tetapi juga dapat dilakukan setelah melahirkan (Sujiyanti dkk, 2010).

Berkaitan dengan ASI, bidan memiliki tugas utama diantaranya seperti memberdayakan perawatan payudara serta mengatasi masalah laktasi dan memantau keadaan ibu dan bayi (Rukiyah, 2008). Perawatan payudara setelah melahirkan antara lain bertujuan untuk memelihara kebersihan payudara agar terhindar dari infeksi, meningkatkan produksi ASI dengan merangsang kelenjar-kelenjar air susu melalui pemijatan, mencegah bendungan ASI atau pembengkakan payudara, melenturkan dan menguatkan puting, mengetahui secara dini kelainan puting susu dan melakukan usaha untuk mengatasinya, serta persiapan psikis ibu menyusui (Pramitasari dan Sayono, 2009).

Masalah laktasi yang sering terjadi pada ibu nifas salah satunya adalah payudara bengkak. Payudara bengkak biasanya terjadi pada hari-hari pertama kelahiran bayi, hal ini dapat terjadi karena terlambat menyusukan dini, ASI kurang sering dikeluarkan serta adanya batasan waktu menyusui. Selain itu penggunaan bra yang ketat serta keadaan puting susu yang tidak bersih dapat menyebabkan sumbatan pada duktus (Roische dan Saryono, 2009).

Perawatan payudara sendiri memiliki pengertian ialah suatu tindakan yang dilakukan untuk merawat payudara terutama pada masa nifas untuk memperlancar ASI (Taufan Nugroho, 2014). Perawatan payudara pasca persalinan merupakan kelanjutan dari perawatan payudara semasa hamil (Sujiyanti dkk, 2010). Perawatan payudara pada ibu menyusui begitu penting karena salah satu manfaatnya yaitu untuk melancarkan produksi ASI yang merupakan makanan pokok pada bayi. Pelaksanaan perawatan payudara pasca persalinan ini dimulai sedini mungkin yaitu 1-2 
hari sesudah bayi dilahirkan hal ini dilakukan 2 kali sehari (Sujiyanti dkk, 2010).

Payudara sama sensitifnya dengan organ intim wanita lainnya. Jangan menggunakan obat-obatan yang justru akan merusak payudara. Jika berniat melakukan perawatan payudara dengan menggunakan obat-obatan atau teknik perawatan payudara, sebaiknya konsultasi dulu dengan ahlinya (Kristiyanasari, 2009).

Pada negara berkembang, khususnya di daerah yang berpenduduknya rendah, pengetahuan ibu mengenai perawatan payudara masih kurang. Umumnya pengetahuan tentang perawatan payudara di peroleh dari keluarga ataupun teman. Untuk menghindari kebiasaan yang salah diperlukan bantuan petugas kesehatan yang dapat memberikan arahan yang tepat (Permatasari dan Saryono, 2009). Pengetahuan merupakan hasil dari tahu, dan ini terjadi setelah orang melakukan pengindraan terhadap suatu objek tertentu sedangkan sikap merupakan reaksi atau respon yang masih tertutup dari seseorang terhadap suatu stimulus atau objek (Safitri, 2011).

Hubungan antara tingkat pengetahuan dengan sikap ibu nifas dalam melakukan perawatan payudara memiliki hubungan, karena dengan ditunjang pengetahuan yang baik maka akan mempengaruhi sikap ibu untuk melakukan perawatan payudara secara baik, benar dan teratur sehingga hak-hak bayi untuk memperoleh ASI akan terpenuhi.

Penelitian yang dilakukan oleh Aghnia Kamila yang dilakukan pada tahun 2014 dengan judul "Hubungan Pengetahuan dan Sikap dengan Perawatan Payudara di Rumah Sakit ibu dan Anak Banda Aceh" didapatkan hasil penelitian dari 86 orang, $49(57,0 \%)$ responden berpengetahuan baik dan 37 (43,0\%) responden berpengetahuan kurang dengan sikap ibu nifas terhadap perawatan payudara $41(47,7 \%)$ responden memiliki sikap positif dan 45 $(52,3 \%)$ memiliki sikap negatif. Melalui uji statistik didapatkan bahwa nilai p-value 0,001 0,005 sehingga hipotesis Ha diterima dan Ho di tolak, hal ini berarti bahwa ada hubungan pengetahuan dan sikap ibu nifas dengan perawatan payudara.

Penelitian yang dilakukan oleh Nina Rahmadiliyani tahun 2012 dengan judul "Hubungan Pengetahuan dan Sikap ibu Nifas Tentang Perawatan Payudara dengan Motivasi Menyusui di RSUD Datu Sanggul Rantau” di dapatkan hasil penelitian ibu nifas berpengetahuan baik sebanyak 20 orang $(22,2 \%)$, ibu nifas berpengetahuan cukup sebanyak 15 orang $(16,7 \%)$ dan ibu nifas berpengetahuan kurang sebanyak 11 orang $(12,2 \%)$ dengan sikap ibu nifas mendukung 25 $(27,8 \%)$ responden dan yang tidak mendukung $18(20 \%)$ responden. Hasil uji statistik chisquare diperoleh nilai $\mathrm{p}=0,001$, dengan nilai $\mathrm{p}$ $(=0,05)$, maka dapat disimpulkan bahwa hipotesis diterima, yang artinya ada hubungan pengetahuan dan sikap ibu nifas tentang perawatan payudara dengan motivasi menyusui di ruang nifas RSUD Data Sanggul Rantau.

Salah satu Rumah Sakit yang berada di Kubu Raya adalah Rumah Sakit Kartika Husada Tingkat II yang bertugas melayani seluruh TNI dan PNS serta melayani masyarakat umum selama 24 jam, yang mana pada tanggal 1 Januari 2014 terdapat pergantian sistem 
pelayanan Rumah Sakit menjadi sistem pelayanan rujukan sampai saat ini.

\section{Metode}

Penelitian ini menggunakan jenis penelitian deskriptif korelasional dengan pendekatan cross sectional. Penelitian dilaksanakan pada bulan April hingga Mei 2017 di Rumah Sakit Kartika Husada Kabupaten Kubu Raya Provinsi
Kalimantan Barat. Populasi penelitian yaitu seluruh ibu nifas yang mendapat pelayanan kesehatan di Rumah Sakit Kartika Husada sebanyak 40 orang. Peneliti menggunakan total sampling sebanyak 40 orang. Pengumpulan data menggunakan kuesioner kemudian diolah dan dianalisis menggunakan analisis univariat serta analisis bivariat menggunakan uji chi square.

\section{Hasil dan Pembahasan}

Tabel 1. Karakteristik Responden

\begin{tabular}{lcc}
\hline \multicolumn{1}{c}{ Karakteristik } & $\mathrm{n}$ & $\%$ \\
\hline Pengetahuan & & \\
$\quad$ Kurang & 21 & 52,5 \\
Cukup & 10 & 25 \\
Baik & 9 & 22,5 \\
Sikap & & \\
$\quad$ Tidak Mendukung & 21 & 52,5 \\
$\quad$ Mendukung & 19 & 47,5 \\
\hline
\end{tabular}

Dilihat dari tabel 1 diatas dapat diketahui bahwa dari 40 responden, sebagian besar responden yaitu 21 orang $(52,5 \%)$ berpengetahuan kurang dan sangat sedikit dari responden yaitu 9 orang $(22,5 \%)$ berpengetahuan baik tentang perawatan payudara. Berdasarkan tabel 1 diatas diketahui bahwa sebagian dari responden yaitu 21 orang $(52,5 \%)$ memiliki sikap tidak memilih terhadap perawatan payudara selama masa nifas.

Tabel 2. Analisis Hubungan Pengetahuan dengan Sikap Istri dalam Perawatan Payudara

\begin{tabular}{|c|c|c|c|c|c|c|c|c|}
\hline \multirow{3}{*}{ Variabel } & \multicolumn{4}{|c|}{ Sikap } & \multirow{2}{*}{\multicolumn{2}{|c|}{ Total }} & \multirow{2}{*}{ OR } & \multirow{3}{*}{ P Value } \\
\hline & \multicolumn{2}{|c|}{ Memilih } & \multicolumn{2}{|c|}{ Tidak Memilih } & & & & \\
\hline & $\mathrm{n}$ & $\%$ & $\mathrm{n}$ & $\%$ & $\mathrm{n}$ & $\%$ & & \\
\hline Baik & 17 & 81 & 4 & 19 & & 100 & & \\
\hline Pengetahuan Cukup & 3 & 30 & 7 & 70 & & 100 & 0,189 & 0,001 \\
\hline Kurang & 1 & 11,1 & 8 & 88,9 & & 100 & & \\
\hline
\end{tabular}

Berdasarkan hasil penelitian yang dilakukan oleh peneliti yang dapat dilihat dari diagram 2 didapatkan hasil responden sebagian kecil dari responden yang berpengetahuan baik tentang perawatan payudara yaitu sebanyak 9 orang $(22,5 \%)$ begitu pula halnya dengan sebagian kecil sekali responden yang berpengetahuan cukup yaitu sebanyak 10 orang $(25,0 \%)$. Sementara itu sebagian responden yang telah mengisi kuisioner berpengetahuan kurang yaitu sebanyak 21 orang $(52,5 \%)$.

Menurut Safitri (2011) pengetahuan merupakan hasil dari tahu, dan ini terjadi setelah orang melakukan pengindraan terhadap 
suatu objek tertentu. Pengindraan terjadi melalui panca indra manusia, yakni indra penglihatan, pengetahuan diperoleh melalui mata dan telinga. Pengetahuan atau kognitif merupakan dominan yang sangat penting dalam membentuk tindakan seseorang (over behavior).

Menurut peneliti pengetahuan merupakan hasil yang nantinya akan diperoleh dari seseorang yang telah tahu atau mendapatkan informasi setelah orang tersebut melakukan kontak atau pengamatan terhadap suatu hal atau objek pengindraan. Berdasarkan hasil jawaban responden diketahui bahwa seluruh responden yang terdiri dari 40 (100\%) orang responden dapat menjawab dengan benar pada soal pengetahuan nomor 2 yaitu tentang pengertian perawatan payudara pada masa nifas, dan hampir seluruh responden yaitu sebanyak $32(80,0 \%)$ orang responden menjawab salah pada soal pengetahuan nomor 13 yaitu tentang pengurutan pada langkah ketiga dalam perawatan payudara.

Menurut Saleha (2009) Perawatan payudara merupakan perawatan yang dilakukan pada ibu pasca bersalin untuk mencegah tersumbatnya saluran susu sehingga memperlancar pengeluaran ASI. Menurut (Anggraini, 2010) Perawatan payudara pada masa nifas adalah suatu tindakan merawat payudara yang dilaksanakan baik oleh pasien maupun dibantu orang lain yang dilaksanakan mulai dari hari pertama atau kedua setelah melahirkan dengan tujuan untuk memperlancar ASI, menghindari terjadinya pembengkakan dan kesulitan menyusui.

Hasil penelitian yang dilakukan oleh
Aghnia Kamila yang dilakukan pada tahun 2014 dengan judul "Hubungan Pengetahuan dan Sikap dengan Perawatan Payudara di Rumah Sakit ibu dan Anak Banda Aceh" dengan hasil penelitian menunjukkan bahwa sebagian responden memiliki pengetahuan baik yaitu $49(57,0 \%)$ sementara itu sebagian responden berpengetahuan kurang yaitu $37(43,0 \%)$.

Hasil penelitian yang dilakukan oleh Nina rahmadiliyani tahun 2012 dengan judul "Hubungan Pengetahuan dan Sikap ibu Nifas Tentang Perawatan Payudara dengan Motivasi Menyusui di RSUD Datu Sanggul Rantau" dengan hasil penelitian menunjukkan bahwa sebagian kecil responden berpengetahuan baik yaitu $20(22,2 \%)$, sangat sedikit responden berpengetahuan cukup yaitu $15(16,7 \%)$ serta sangat sedikit responden berpengetahuan kurang $11(12,2 \%)$ dengan sikap ibu nifas mendukung $25(27,8 \%)$ responden dan yang tidak mendukung 18 (20\%) responden.

Hasil penelitian yang dilakukan oleh peneliti di Rumah Sakit Kartika Husada kepada 40 orang responden ibu nifas mengenai perawatan payudara didapatkan hasil bahwa sebagian kecil dari responden yang berpengetahuan baik tentang perawatan payudara yaitu sebanyak 9 orang $(22,5 \%)$ begitu pula halnya dengan sebagian kecil sekali resonden yang berpengetahuan cukup yaitu sebanyak 10 orang $(25,0 \%)$. Sementara itu sebagian responden yang telah mengisi kuisioner berpengetahuan kurang yaitu sebanyak 21 orang $(52,5 \%)$. Kurangnya pengetahuan ibu nifas mengenai perawatan payudara disebabkan karena status pendidikan 
ibu yang hanya sebatas bangku sekolah dasar, status pekerjaan ibu yang hanya menjadi ibu rumah tangga biasa serta kurangnya pengetahuan atau informasi yang ibu dapatkan mengenai perawatan payudara dan kurangnya rasa ketertarikan ibu atau minta untuk mencari tahu tentang perawatan payudara, tujuan berserta langkah-langkah perawatan payudara yang benar.

Jika ibu nifas memiliki rasa ketertarikan atau minta yang besar untuk mencari informasi yang benar mengenai perawatan payudara atau memahami tentang tujuan perawatan payudara yang diantaranya adalah untuk memelihara kebersihan payudara agar terhindar dari infeksi, meningkatkan produksi ASI dengan merangsang kelenjar-kelenjar air susu melalui pemijatan, mencegah bendungan ASI atau pembengkakan payudara, melenturkan dan menguatkan puting, mengetahui secara dini kelainan puting susu dan melakukan usaha untuk mengatasinya serta, persiapan psikis ibu menyusui maka dengan di dorong informasi yang didapatkan tersebut baik ibu pasti akan terdorong untuk melakukan perawatan payudara dikarenakan telah memahami tentang pentingnya perawatan payudara perawatan tersebut.

Sementara masih sangat sedikit sekali responden yang berpengetahuan baik yaitu sebanyak sebanyak 9 orang $(22,5 \%)$ dan yang berpengetahuan cukup yaitu sebanyak 10 orang $(25,0 \%)$. Responden yang berpengetahuan baik dan cukup hal ini disebabkan karena tingkat pendidikannya lebih tinggi serta ibu nifas mendapatkan informasi mengenai perawatan payudara dan memiliki minat untuk mencari tahu mengenai pentingnya melakukan perawatan payudara, ibu nifas juga mampu untuk mengetahui, mengaplikasikan, menganalisis, mensintesiskan serta mengevaluasi mengenai pentingnya melakukan perawatan payudara pada masa nifas.

Berdasarkan hasil penelitian yang dilakukan oleh peneliti yang dapat dilihat dari tabel 2 didapatkan hasil sebagian responden memiliki sikap tidak mendukung terhadap perawatan payudara yaitu sebanyak 21 orang $(52,5 \%)$, begitu pula halnya dengan sebagian dari responden juga memiliki sikap mendukung terhadap perawatan payudara yaitu sebanyak 19 orang $(47,5 \%)$. Sesuai dengan pendapat Safitri (2010) bahwa sikap merupakan reaksi atau respon yang masih tertutup dari seseorang terhadap suatu stimulus atau objek yang tentu saja telah dipengaruhi oleh pengetahuan yang didapat oleh individu tersebut sebelumnya.

Menurut peneliti sikap adalah tanggapan dari seseorang individu terkait suatu hal mengenai suatu objek untuk ditanggapi atau tindakan yang akan dilakukannya mengenai hal tersebut, sebagai contoh tindakan seseorang untuk mau atau bersedia melakukan perawatan payudara setelah dipengaruhi oleh pengetahuan. Berdasarkan hasil jawaban dari 40 orang responden tentang pertanyaan sikap sebagian responden $19(47,5 \%)$ sangat setuju pertanyaan postif nomor 1 mengenai perawatan payudara, sedangkan hampir seluruh responden 35 $(87,5 \%)$ menjawab tidak setuju pertanyaan negatif nomor 6 mengenai melakukan perawatan payudara akan membuat puting susu lecet.

Hasil penelitian yang dilakukan oleh 
Aghnia Kamila yang dilakukan pada tahun 2014 dengan judul "Hubungan Pengetahuan dan Sikap dengan Perawatan Payudara di Rumah Sakit ibu dan Anak Banda Aceh " di dapatkan hasil bahwa sebagian responden memiliki sikap positif atau mendukung terhadap perawatan payudara sebesar $41(47,7 \%)$ dan sebagian responden memiliki sikap negatif atau tidak mendukung terhadap perawatan payudara sebesar $45(52,3 \%)$.

Hasil penelitian yang dilakukan oleh Nina rahmadiliyani tahun 2012 dengan judul "Hubungan Pengetahuan dan Sikap ibu Nifas Tentang Perawatan Payudara dengan Motivasi Menyusui di RSUD Datu Sanggul Rantau" dengan hasil menunjukkan bahwa sebagian kecil responden memiliki sikap positif atau mendukung terhadap perawatan payudara sebesar 21(23,3\%) dan sebagian kecil responden sikap negatif atau tidak mendukung terhadap perawatan payudara sebesar $18(20 \%)$.

Hasil penelitian yang dilakukan oleh peneliti di Rumah Sakit Kartika Husada kepada 40 orang responden ibu nifas mengenai perawatan payudara didapatkan hasil bahwa sebagian responden memiliki sikap tidak mendukung terhadap perawatan payudara yaitu sebanyak 21 orang $(52,5 \%)$, begitu pula halnya dengan sebagian dari responden juga memiliki sikap mendukung terhadap perawatan payudara yaitu sebanyak 19 orang $(47,5 \%)$. Sikap tersebut ditunjukkan dari kesadaran ibu nifas mengenai perawatan payudara yang ditunjukkan sikap mendukung dengan menjawab pertanyaan setuju atau sangat setuju mengenai kuisioner yang peneliti berikan kepada responden yaitu pertanyaan mengenai seberapa pentingnya melakukan perawatan payudara setelah melahirkan dan untuk menghindari pembengkakan payudara, kebersihan yang harus dilakukan agar payudara terhindar dari infeksi, serta pengurutan yang dilakukan dalam melakukan perawatan payudara.

Sikap tidak mendukung ditunjukkan responden mengenai perawatan payudara dengan menjawab pertanyaan tidak setuju dan sangat tidak setuju dengan apa yang harus dilakukan terhadap sikap dalam melakukan perawatan payudara. Berdasarkan pada tabel 2 yang merupakan hasil gabungan antara pengetahuan dan sikap ibu nifas terhadap perawatan payudara menunjukkan bahwa sangat sedikit dari responden (19\%) yaitu 4 orang berpengetahuan kurang dengan sikap mendukung terhadap perawatan payudara. Hasil pengetahuan responden yang berpengetahuan baik dengan hasil hampir seluruh responden $(88, \%)$ yaitu 8 orang memiliki pengetahuan baik dengan sikap mendukung terhadap perawatan payudara.

Hasil uji statistik yang telah diuraikan pada tabel 2 diperoleh nilai Chi-Square sebesar $0,01$ (p-value $<0,05)$ sehingga dapat disimpulkan bahwa ada hubungan antara pengetahuan ibu nifas dengan sikap dalam melakukan perawatan payudara di Rumah Sakit Kartika Husada tahun 2017. Berdasarkan hasil pengetahuan dan sikap reponden didapatkan hasil hubungan antara pengetahuan dengan sikap ibu nifas dalam melakukan perawatan payudara memiliki hubungan, karena dengan ditunjang pengetahuan yang baik maka akan 
mempengaruhi sikap ibu untuk melakukan perawatan payudara secara baik, benar dan teratur sehingga hak-hak bayi untuk memperoleh ASI akan terpenuhi.

Hal ini sejalan dengan penelitian yang dilakukan oleh Aghnia Kamila yang dilakukan pada tahun 2014 dengan judul "Hubungan Pengetahuan dan Sikap dengan Perawatan Payudara di Rumah Sakit ibu dan Anak Banda Aceh" penelitian ini menggunakan desain penelitian diskriptif korelatif dengan pendekatakan cross sectional study, teknik pengambilan sampel menggunakan purposive sampling, teknik pengumpulan data mengunakan kuisioner dengan teknik analisis data menggunakan uji chi square dengan hasil bahwa nilai p-value $0,01 \quad 0,05$ sehingga hipotesis Ha diterima dan Ho di tolak, hal ini berarti bahwa ada hubungan pengetahuan dan sikap ibu nifas dengan perawatan payudara.

Jadi dari hasil penelitian yang dilakukan oleh peneliti pada bulan April dengan cara membagikan kuesinor pengetahuan dan sikap kepada 40 orang ibu nifas dapat di simpulkan bahwa pengetahuan mempengaruhi sikap ibu nifas dalam melakukan perawatan payudara sehingga terdapatnya hubungan antara pengetahuan dengan sikap ibu nifas dalam melakukan perawatan payudara di Rumah Sakit Kartika Husada pada tahun 2017.

\section{Kesimpulan}

Kesimpulan penelitian ini yaitu ada hubungan antara pengetahuan ibu nifas dengan sikap dalam melakukan perawatan payudara di Rumah Sakit Kartika Husada tahun 2017. Saran kepada petugas kesehatan untuk melakukan penyuluhan tentang perawatan payudara dengan cara membagikan brosur, leaflet atau menempelkan gambar tentang perawatan payudara.

\section{Daftar Pustaka}

Alimul, Aziz. 2014. Metode Penelitian Kebidanan \& Teknik Analisis Data. Jakarta: Salemba

Arikunto, Suharsimi. 2010. Prosedur Penelitian Suatu Pendekatan Praktik. Jakarta: Rineka Cipta

2011 Prosedur Penelitian Suatu Pendekatan Praktik. Jakarta: Rineka Cipta

Azwar, Saifuddin. 2011. Sikap ManusiaTeori Dan Pengukurannya. Yogyakarta: Pustaka Pelajar

Billings, Evelyn.L. 2007. Mengenal Metode Ovulasi Billings. Yogyakarta: PT. Kanisius

BKKBN. 2009. Profil BKKBN Tahun 2009. https://www.bkkbn.go.id/ diakses: 12 Maret 2017, 20.10 WIB

2016. Profil BKKBN Tahun 2016.https://www.bkkbn.go.id/ diakses: 16 Maret 2017, 19.35 WIB

20017. Visi dan Misi Keluarga Berencana. https://www.bkkbn.go.id/ diakses: 19 Maret 2017, 18.20 WIB

Depkes RI. 2014. Riset Kesehatan Dasar (Riskesdas) $2013-$ Kemenkes. www.depkes.go.id diakses: 14 Maret 2017, 11.20 WIB

Everett, Suzanne. 2008. Kontrasepsi \& Kesehatan Seksual Reproduktif. Jakarta: EGC

Erniyawati, Dwi. 2007. Pengetahuan dan Motivasi Tentang Kontrasepsi Pada Akseptor KB Di 4 Taman Kanak-Kanak 
Di Kecamatan Sleman. https://repository.usd.ac.id/2804/2/ 998114224_Full.pdf, diakses : 01 Maret, 09.20 WIB

Fitriani, Sinta. 2011. Promosi Kesehatan. Yogyakarta: GRAHA ILMU

Handayani, Sri. 2010. Pelayanan Keluarga Berencana. Yogyakarta: Pustaka Rihama

Irianto, Koes. 2014. Pelayanan Keluarga Berencana. Bandung: ALFABETA

Kartadibata, H. Sunaryo. (2010). Pedoman Karya Tulis Ilmiah. Bandung: Universitas Pendidikan Indonesia

Klein, Paul \& Team KBA. 2010. Keluarga Berencana Alamiah? Mengapa Tidak. Malang: Dioma

Marmi. 2015. Kesehatan Reproduksi. Yogyakarta: Pustaka Pelajar

Maulana, Heri D.J. 2007. Promosi Kesehatan. Jakarta: EGC Jakarta: EGC

2009. Promosi Kesehatan. 2013. Promosi Kesehatan. Jakarta: EGC

Mubarak, Wahit Iqbal, dkk. 2012. Promosi Kesehatan: Sebuah Pengantar Proses Belajar Mengajar dalam Pendidikan. Yogyakarta: Candi Gebang Permai

Notoatmodjo, Soekidjo. 2010. Metodologi Penelitian Kesehatan. Jakarta: Rineka Cipta

2012. Metodologi Penelitian Kesehatan. Jakarta: Rineka Cipta

Pendit, B.U. 2007. Ragam Metode Kontrasepsi. Jakarta: EGC

Pinem, Saroha. 2009. Kesehatan Reproduksi dan Kontrasepsi. Jakarta: CV. Trans Info Media

Proverawati, Atikah dkk. 2010. Panduan Memilih Kontrasepsi. Yogyakarta: Nuha Medika
Riwidikdo, Handoko. 2008. Statistik Kesehatan. Jogjakarta: Mitra Cendika Sabri, Luknis dan Sutanto Priyo Hastono. 2014. Statistik Kesehatan. Jakarta: Rajawali Pers

Sari, Eka Wahyu. 2008. "OB Ovulasi Billings Masuk Desa": Program Pengenalan Metode Alternatif Keluarga Berencana Di Kelurahan Balumbang Jaya. http://repository.ipb.ac.id/jspui/bitstream /123456789/6/WahyuEkaSari

PKMGT.doc diakses : 01 Maret 2017, 08.35 WIB

Sugiyono. 2011. Statistika untuk Penelitian. Bandung: ALFABETA

2012. Statistika untuk Penelitian. Bandung: ALFABETA

2014. Statistika untuk Penelitian. Bandung: ALFABETA

Sulistyawati, Ari. 2011. Pelayanan Keluarga Berencana. Jakarta: Salemba Medika

Survei Sosial Ekonomi Nasional. 2015. Analisis Data Kependudukan dan KB Hasil Susenas 2015. kalbar.bkkbn.go.id diakses: 28 Februari 2017, 14.00

Susila dan Suyanto. 2014. Metodologi Penelitian Cross Sectional. Klaten: BOSSSCRIPT.

Suyanto, dkk. 2014. Metodologi Penelitian Kesehatan dan Kedokteran. Yogyakarta: Bursa Ilmu

Uliyah, Mar'atul. 2010. Panduan Aman dan Sehat Memilih Alat KB. Yogyakarta: PT. Pustaka Insan Madani

WHO. 2015. The World Health Report 2015. http://www.who.int/mediacentre /factsheet/fs351/en/ diakses : 12 Maret 2017, 16.30 WIB 